\title{
PERBANDINGAN POLA RETAK DAN LENDUTAN PADA PELAT BETON MENGGUNAKAN TULANGAN KONVENSIONAL DAN WIREMESH
}

\author{
Nawir Rasidi \\ Jurusan Teknik Sipil, Politeknik Negeri Malang \\ email : nawir.rasidi@polinema.ac.id \\ (Artikel diterima: Februari 2020, direvisi: April 2020, diterima untuk terbit: Juli 2020)
}

\begin{abstract}
Abstrak - Penelitian dengan judul melakukan Pengujian Eksperimental Perbandingan Pola Retak dan Lendutan pada Pelat Beton Menggunakan Tulangan Konvensional dan Wiremesh adalah untuk mengetahui perbandingan nilai kuat tarik tulangan konvensional dan tulangan wiremesh dan mengetahui nilai kuat lentur pelat tulangan konvensional dan pelat tulangan wiremesh serta mengetahui perbandingan pola retak antara pelat lantai tulangan konvensional dan pelat lantai tulangan wiremesh. Pada penelitian ini dilakukan dengan membuat beberapa pelat beton. Tidak hanya menguji kuat lentur, penelitian ini juga menguji karakteristik material sampai dengan uji kuat tekan beton dan uji kuat tari tulangan pelat. Tulangan pelat menggunakan besi tulangan polos diameter $6 \mathrm{~mm}$ dan $8 \mathrm{~mm}$ dimana tulangan konvensional dirakit menggunakan bendrat. Pelat nantinya dibandingkan dengan pelat bertulangan wiremesh menggunakan ukuran M6 dan M8. Kedua pelat diuji lentur dengan beban terpusat dan hasil pengujian keduanya dibandingkan. Pada uji kuat lentur pelat beton bertulang di laboratorium diperoleh beban maksimum dari dua jenis pelat tersebut, dimana beban maksimum pelat beton dengan tulangan konvensional pada tulangan polos diameter $6 \mathrm{~mm}$ ialah $\varnothing 6=45000 \mathrm{Kg} . \mathrm{cm}$ sedangkan pada pelat beton dengan tulangan wiremesh ialah M6 $=42500 \mathrm{Kg} . \mathrm{cm}$ kemudian pada tulangan diameter $8 \mathrm{~mm}, \varnothing 8=32500 \mathrm{Kg} . \mathrm{cm}$ sedangkan M8 $=57500 \mathrm{Kg} . \mathrm{cm}$. Sesuai hasil pengamatan penelitian, pelat beton dengan tulangan wiremesh lebih menunjukan perilaku kemampuan menerima beban, serta momen kapasitas yang lebih baik dalam melentur dibanding dengan pelat konvensional.
\end{abstract}

Kata kunci: pelat beton, uji lentur, tulangan konvensional, wiremesh.

\section{Pendahuluan}

Dengan perkembangan pembangunan infrastruktur (konstruksi) di berbagai tempat menuntut adanya kemajuan teknologi maupun terobosan-terobosan terbaru demi memperlancar dan mendukung perkembangan infrastruktur tanpa mengabaikan kualitas maupun nilai estetikanya.

Pelat lantai merupakan salah satu bagian dari pekerjaan konstruksi pada bangunan bertingkat dua atau lebih. Pelat lantai pada dasarnya dibuat dengan menggunakan bekisting multiplek dengan tulangan yang direkatkan dengan kawat lalu diselimuti dengan beton. Seiring dengan perkembangan inovasi maka munculah wiremesh, half slab maupun terobosan terbaru lainnya, tapi apakah inovasi-inovasi ini telah meninjau segi kualitas?

Melihat dari beberapa jurnal terkait seperti "Analisis Perbandingan Waktu, Biaya, dan Direct Waste Penggunaan Tulangan Konvensional, Wire Mesh, dan Floordeck pada Pekerjaan Pelat Lantai" yang melihat dari segi biaya, waktu dan direct waste. Lalu ada pula jurnal dengan judul "Kajian Kuat Lentur Pelat Bertulang Biasa dan Pelat Beton Bertulangan Kayu dan Bambu pada Tumpuan Sederhana" membahas tentang membandingkan kuat lentur pelat beton bertulangan baja dengan pelat beton bertulangan kayu yang memiliki kekuatan yang setara, untuk mengetahui kenaikan kuat lentur pelat beton bertulangan kayu, jika diperkuat dengan bambu, dan untuk mengetahui perbedaan kuat lentur pelat beton bertulang secara pengujian dengan kuat lentur pelat beton bertulang secara analisis.

\section{TINJAUAN PUSTAKA}

\section{A. Beton}

Beton merupakan material yang berupa seperti batu, diperoleh dari membuat suatu campuran dengaan proporsi tertentu dari semen, pasir, dan kerikil, serta air yang membuat campuran tersebut bisa menjadi keras dalam cetakan dengan sesuai dimensi dan kebutuhan.

Beton selalu menjadi bahan utama untuk pekerjaan konstruksi. Bila kita lihat pada pekerjaan konstruksi, semua menggunakan beton sebagai material utama. Beton banyak digunakan karena beton mudah dibentuk sesuai dengan kebutuhan konstruksi, beton juga sangat kuat terhadap beban yang berat serta memiliki ketahanan terhadap temperatur tinggi.

\section{B. Pelat}

Pelat adalah elemen struktur datar yang memiliki ketebalan yang lebih kecil dari dimensi lainnya. Menurut Scholdek (1998) dalam bukunya berjudul Sturcture mendefinisikan pelat yaitu struktur planar kaku yang secara khas terbuat dari material monolit yang tingginya kecil dibandingkan dengan dimensi-dimensi lainnya. Beban yang umum bekerja pada pelat mempunyai sifat banyak arah dan tersebar.

Pada pelat lantai hanya diperhitungkan adanya beban tetap saja (penghuni, perabotan, berat lapis tegel, berat sendiri pelat) yang bekerja secara tetap dalam waktu lama. Sedangkan beban seperti gempa, angin dan getaran tidak diperhitungkan.

Pelat lantai adalah lantai yang tidak terletak dipermukaan tanah, atau bisa disebut lantai tingkat. Pekerjaan pelat lantai ini haruslah kokoh, kaku, mempunyai ketinggian yang sama dan nyaman untuk berpijak.

\section{Kuat Lentur}

Kuat lentur merupakan kemampuan dari suatu bahan untuk menahan beban lentur. Nilai tegangan tarik yang dihasilkan dari momen lentur dibagi dengan momen penahan penampang balok uji. Ketika suatu batang dibebani beban 
lentur, maka batang tersebut dapat mengalami lenturan, geser, dan lendutan. Lendutan yang terjadi pada suatu batang lentur dapat ditentukan dari gaya luar, panjang bentang, momen inersia penampang, dan modulus elastisitas.

\section{Konvensional}

Metode Konvensional yaitu pengerjaan perakitan tulangan beton bertulang yang dilakukan ditempat, dengan bekisting yang menggunakan polywood dengan perancah scaffolding. Ini adalah cara yang masih terbilang 'kuno' dan memakan banyak waktu dan biaya, sehingga banyak yang berlomba-lomba untuk mendapatkan inovasi terbaru dan untuk mendapatkan waktu yang cepat dan biaya yang murah.

\section{E. Wiremesh}

wiremesh adalah rangkaian baja tulangan bermutu tinggi (dengan tegangan leleh karakteristik sampai 5.000 $\mathrm{kg} / \mathrm{cm} 2$ ) berbentuk jaring-jaring dengan spasi tertentu yang pada tiap titik pertemuannya dihubungkan dengan las listrik. Wiremesh dijadikan terobosan terbaru terhadap tulangan beton bertulang yang menggunakan metode konvensional. Wiremesh telah terbukti secara penelitian dapat mengurangi waktu proses pembangunan.

\section{MeMetode Penelitian}

\section{A. Diagram Alir Penelitian}

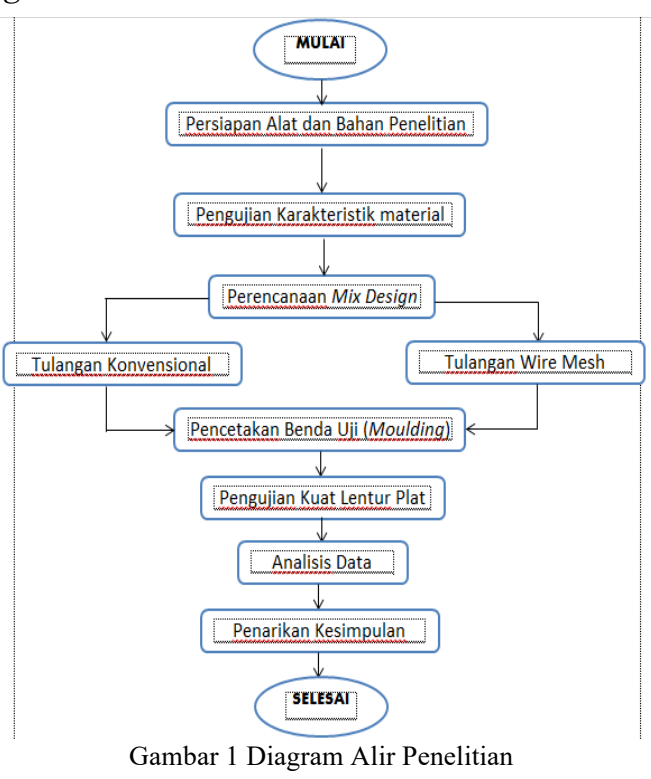

\section{B. Jumlah dan Perlakuan Benda Uji}

Dalam penelitian ini dibuat 5 buah beton silinder untuk uji kuat tekan, 8 buah besi untuk uji kuat tarik tulangan beton yang terdiri dari 4 tulangan besi polos yang digunakan sebagai tulangan yang menggunakan metode konvensinal dan 4 buah tulangan wiremesh dimana panjang tiap tulangan 20 $\mathrm{cm}$, dan dilakukan uji kuat lentur pelat beton bertulang dengan jumlah benda ujinya 8 buah yang terdiri dari 4 pelat dengan tulangan konvensional dan 4 lainnya dengan tulangan wiremesh.

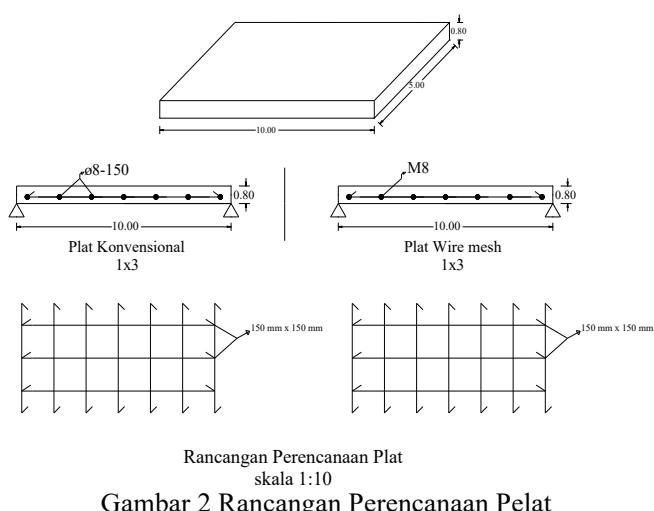

\section{Hasil Dan Pembahasan}

\section{A. Analisis Bahan Penyusun Pelat}

Sebelum melakukan pembebanan pada pelat, dilakukan terlebih dahulu pada sampel beton untuk mengetahui kekuatan beton. Sampel pengujian beton menggunakan beton berbentuk silinder dengan dimensi diameter $15 \mathrm{~cm}$ dan tinggi $30 \mathrm{~cm}$. Dari hasil uji kuat tekan beton, diperoleh kekuatan runtuh rata-rata pada saat beton hancur dengan perbandingan berat campuran 1:2:3 (semen:pasir:kerikil) adalah sebesar 19,3 Mpa.

\begin{tabular}{|c|c|c|c|c|c|}
\hline $\begin{array}{l}\text { Berat } \\
\text { ( Kg) }\end{array}$ & $\begin{array}{c}\text { Dim } \\
(\mathbf{m m})\end{array}$ & $\begin{array}{l}\text { Tinggi } \\
(\mathbf{m m})\end{array}$ & $\begin{array}{c}\text { Luas } \\
\left(\mathbf{m m}^{2}\right)\end{array}$ & $\begin{array}{c}\text { Beban } \\
\text { Tekan } \\
\text { (N) }\end{array}$ & $\begin{array}{c}\text { kuat } \\
\text { tekan } \\
\text { umur } \\
28 \\
\text { hari } \\
\text { (Mpa) } \\
\end{array}$ \\
\hline 12 & 149 & 303 & 17427.78 & 204500 & 18.053 \\
\hline 12.5 & 150 & 300 & 17662.50 & 188500 & 16.419 \\
\hline 12.7 & 150 & 302 & 17662.50 & 222700 & 19.398 \\
\hline 12.1 & 150 & 300 & 17662.50 & 233500 & 20.339 \\
\hline 12.5 & 150 & 300 & 17662.50 & 295300 & 25.722 \\
\hline
\end{tabular}

Sumber : Hasil Analisis

Kekuatan beton sangat tergantung dari agregat yang digunakan, umumnya kekuatan beton terletak pada agregat kasar dan ikatan antar agregat kasar. Dimana ikatan-ikatan tersebut dapat menutup rongga-rongga yang terbentuk pada beton. Semakin banyak agregat kasar yang digunakan maka kekuatan beton juga menjadi tinggi bila sesuai dengan batasan tertentu.

Selama masa perawatan beton menuju umur 28 hari, lingkungan disekitar beton harus diperhatikan kebersihannya, karena jika terdapat bahan-bahan kimia akan mempengaruhi kualitas beton. Masa curing beton dilakukan selama 7 hari mulai dari beton selesai dituangkan dalam bekisting, curing dilakukan dengan menutup permukaan pelat dengan menggunakan karung basah. Setelah 7 hari karung basah dapat dilepas dan pelat akan diuji setelah itu hasil pengujian 7 hari dikonversi ke 28 hari dengan menggunakan PBI 1971.

\section{B. Tulangan Pelat}

Uji tarik rekayasa banyak dilakukan untuk melengkapi informasi rancangan dasar kekuatan suatu bahan dan sebagai data pendukung bagi spesifikasi bahan (Dieter, 1987). Pada uji tarik, benda uji diberi beban gaya tarik sesumbu yang bertambah secara kontinyu, bersamaan dengan 
itu dilakukan pengamatan terhadap perpanjangan yang dialami benda uji. Kurva tegangan regangan rekayasa diperoleh dari pengukuran perpanjangan benda uji. Pada spesimen panjang bagian tengahnya biasanya lebih kecil luas penampangnya dibandingkan kedua ujungnya.

Pada penelitian ini terdapat 8 benda uji tarik dimana tiap sampel terdiri atas 2 benda uji. Adapun hasil penelitiannya dapat dilihat pada table berikut.

Tabel 2 Hasil Uji Kuat Tarik Tulangan Beton

\begin{tabular}{|c|c|c|c|c|c|}
\hline besi & $\begin{array}{l}\Sigma \mathbf{p y} \\
(\mathbf{k N})\end{array}$ & $\begin{array}{c}\text { ¿pmaks } \\
(\mathbf{k N})\end{array}$ & $\begin{array}{c}\text { Aso } \\
(\mathbf{m m} 2)\end{array}$ & $\begin{array}{c}\text { tegangan } \\
\text { leleh } \\
\text { fy } \\
(\mathrm{N} / \mathrm{mm} 2)\end{array}$ & $\begin{array}{c}\text { tegangan } \\
\text { putus } \\
\text { fu } \\
\text { (N/mm2) }\end{array}$ \\
\hline $\begin{array}{l}\text { M8 } \\
\text { M8 }\end{array}$ & 16 & 23.9 & 41.833 & 382.48 & 571.32 \\
\hline $\begin{array}{l}\text { M6 } \\
\text { M6 }\end{array}$ & 12.25 & 17.15 & 25.50 & 480.30 & 672.43 \\
\hline$\frac{\varnothing 6}{\varnothing 6}$ & 11.5 & 18 & 28.26 & 406.94 & 636.94 \\
\hline$\frac{\varnothing 8}{\varnothing 8}$ & 19.5 & 29.55 & 44.16 & 441.61 & 669.21 \\
\hline
\end{tabular}

Sumber : Hasil Analisis

Hasil pengujian kuat tarik menghasilkan nilai tegangan leleh fy dan tegangan putus fu dimana nilai terbesar terdapat pada hasil pengujian kuat tarik tulangan wiremesh M6 dengan nilai fy $=480,30 \mathrm{~N} / \mathrm{mm}^{2}$ dan $\mathrm{fu}=672,43 \mathrm{~N} / \mathrm{mm}^{2}$. Dari tabel di atas menunjukan bahwa baik besi tulangan konvensional maupun besi tulangan wiremesh tegangan lelehnya atau lebih dikenal dengan mutu baja atau "fy" lebih besar dari $240 \mathrm{MPa}$ maka memenuhi standar perencanaan.

\section{Pengujian Kuat Lentur Pelat Dua Arah}

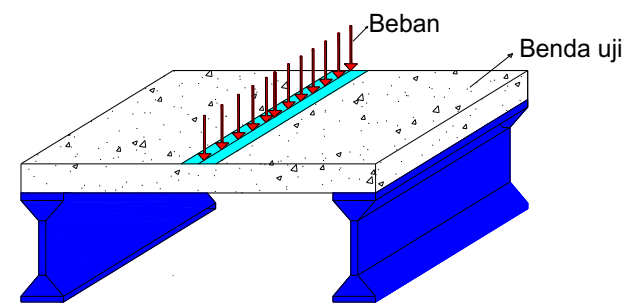

Gambar 3 Gambar Setting Pembebanan Pada Pelat Saat Pengujian Kua Lentur

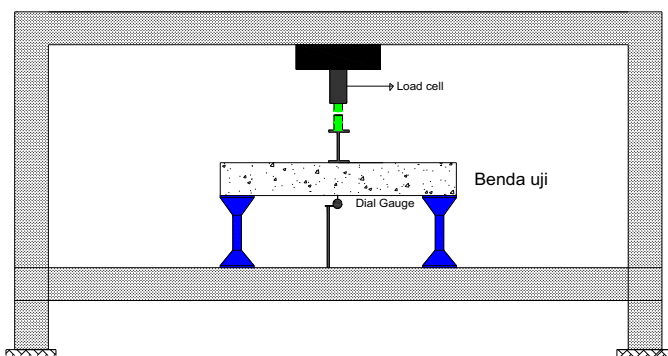

Gambar 4 Benda Uji Saat Diletakkan di Atas Alat Uji

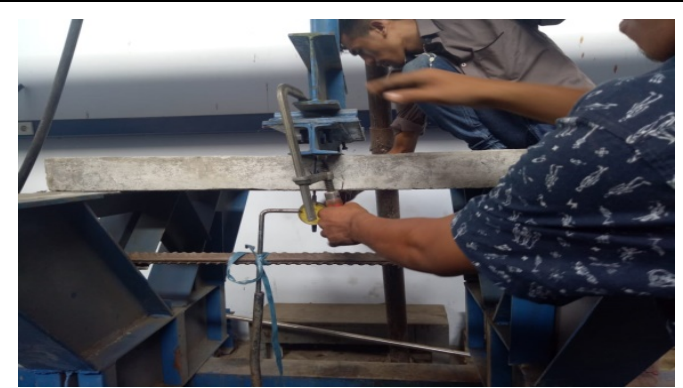

Gambar 5 Persiapan Proses Pengujian Kuat Lentur Pelat

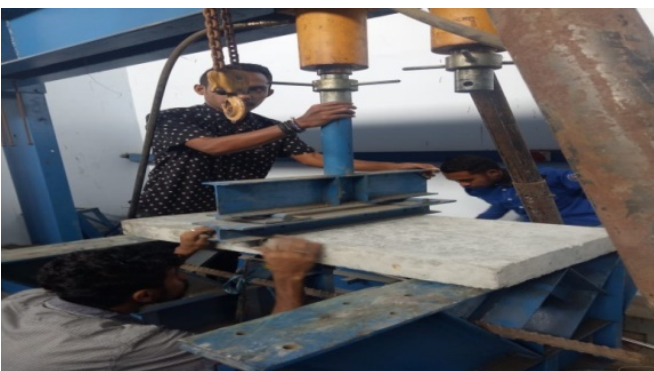

Gambar 6 Tampak Perletakkan Pelat pada Alat Uji

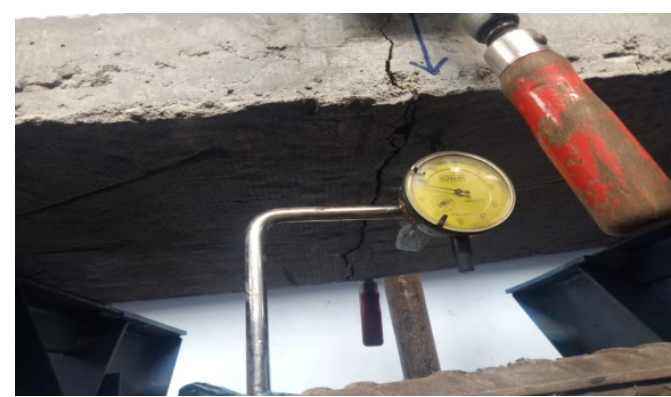

Gambar 7 Pembacaan Dial Gauge pada Saat Pelat dalam Kondisi Krisis Retak

Pada gambar 3 dan gambar 4 menggambarkan penyettingan posisi pelat pada saat pengujian dimana benda uji ditempatkan pada tumpuan di kedua sisinya sama besar, lalu pada bagian atas pelat diletakan besi yang membagi 2 sisi panjang dan lebar pelat sama besarnya kemudian pada besi tersebut diberikan pembebanan setiap kelipatan $100 \mathrm{Kg}$ secara terus-menerus oleh load cell sampai pelat mencapai kondisi retak. Disetiap kelipatan beban $100 \mathrm{Kg}$, lendutan yang terjadi akan ditunjukkan pada alat dial gauge yang berada pada posisi di bawah pelat seperti ditunjukkan pada gambar 4.

Berdasarkan hasil penelitian di dapat nilai maksimum lendutan yang dialami beton serta besarnya beban yang mengakibatkan lendutan pelat beton tersebut sebelum memasuki krisis retak.

Tabel 3 Nilai Maksimum Lendutan yang Dialami Pelat Beton Akibat Beban yang Diberikan

\begin{tabular}{|l|c|c|}
\hline besi & $\begin{array}{c}\text { beban } \\
\text { maksimum } \\
\text { (Kg) }\end{array}$ & $\begin{array}{c}\text { lendutan } \\
\text { maksimum } \\
\text { (mm) }\end{array}$ \\
\hline $\mathbf{8}$ & 1800 & 10.23 \\
\hline M8 & 2300 & 8.045 \\
\hline $\mathbf{6}$ & 1300 & 8.1 \\
\hline M6 & 1700 & 7.555 \\
\hline
\end{tabular}

Sumber : Hasil Analisis

Seperti hasil pada tabel 3 yang menampilkan nilai maksimum lendutan yang dialami pelat beton bertulang akibat beban yang diberikan, dapat dilihat bahwa tulangan wiremesh merupakan tulangan yang paling tinggi menerima 
beban sebelum memasuki kondisi krisis retak atau dapat dikatakan bahwa pelat dengan tulangan wiremesh lebih melentur saat menerima beban dibanding pelat dengan tulangan konvensional.

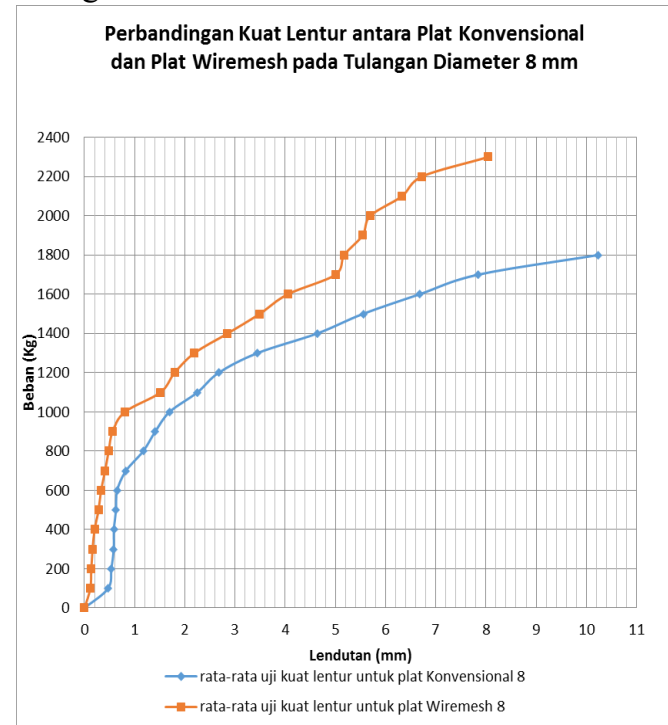

Gambar 8 Grafik Perbandingan Kuat Lentur antara Pelat Konvensional dan Pelat Wiremesh pada Tulangan Diameter $8 \mathrm{~mm}$

Perbandingan hasil uji kuat lentur pelat tulangan konvensional dan pelat tulangan wiremesh dengan diameter tulangan $8 \mathrm{~mm}$ menunjukkan perbedaan dimana pelat dengan tulangan wiremesh lebih mampu menerima beban yang lebig besar dibanding pelat dengan tulangan konvensional.

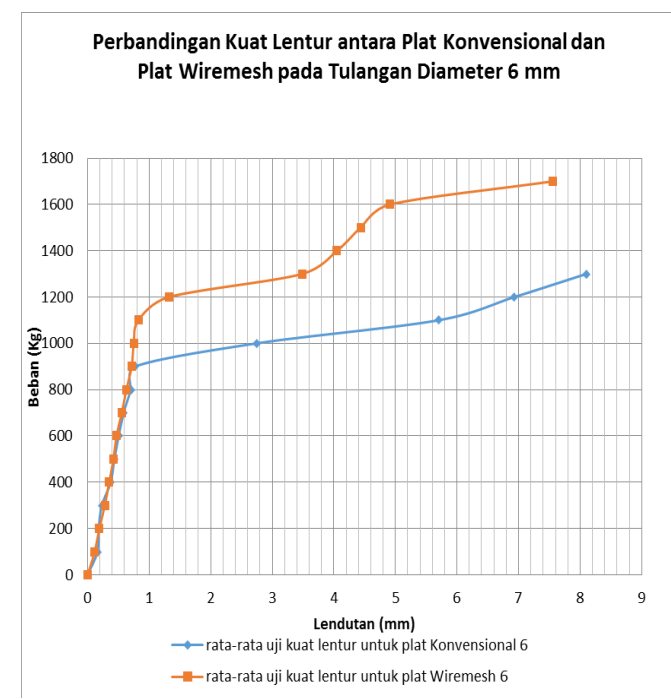

Gambar 9 Grafik Perbandingan Kuat Lentur antara Pelat Konvensional dan Pelat Wiremesh pada Tulangan Diameter $6 \mathrm{~mm}$

Pada grafik yang ditampikan di gambar 5 dan gambar 6 menunjukkan bahwa besi tulangan wiremesh lebih mudah melendut dan mampu menerima beban lebih besar dibanding pelat dengan tulangan konvensional sebelum mencapai kondisi krisis retak.

Hasil perhitungan secara analisis pelat beton bertulang konvensional dan pelat beton bertulang wiremesh. Berdasarkan hasil perhitungan secara analisis, momen kapasitas dan lendutan yang terjadi pada pelat beton bertulangan diatas dapat dilihat pada tabel 3 .
Tabel 4 momen kapasitas dan lendutan yang terjadi pada pelat beton bertulangan Konvensional dan Beton Bertulangan Wiremesh

\begin{tabular}{|c|c|c|c|c|c|c|c|c|c|c|}
\hline kode & $\begin{array}{l}\mathrm{dim} \\
\text { (cm) }\end{array}$ & $\begin{array}{c}P \\
\text { percobaan } \\
(\mathrm{Kg})\end{array}$ & $\begin{array}{c}\mathrm{L} \\
(\mathrm{cm})\end{array}$ & $\begin{array}{c}\text { fy } \\
(\mathrm{Kg} / \mathrm{cm} 2)\end{array}$ & $\begin{array}{c}\mathrm{fc}^{\prime} \\
(\mathrm{kg} / \mathrm{cm} 2)\end{array}$ & $\begin{array}{c}\text { Mmax } \\
(\mathrm{Kg} . \mathrm{cm})\end{array}$ & $\mathrm{T}=\mathrm{CC}$ & $\begin{array}{c}a \\
(\mathrm{~cm})\end{array}$ & $\begin{array}{c}\mathrm{Mn} \\
\text { teori } \\
(\mathrm{Kg} . \mathrm{cm})\end{array}$ & $\begin{array}{c}\text { Pteori } \\
(\mathrm{Kg})\end{array}$ \\
\hline a1 & 0.73 & 2300 & 100 & 2400 & 193 & 57500 & 250.996 & 0.031 & 1251.14 & 50.05 \\
\hline b1 & 0.57 & 1700 & 1 & 2400 & 193 & 42500 & 153.028 & 0.019 & 763.71 & 30.55 \\
\hline$c 1$ & 0.6 & 1800 & 100 & 2400 & 193 & 45000 & 169.560 & 0.021 & 846.05 & 33.84 \\
\hline $\mathrm{d} 1$ & 0.75 & 1300 & 100 & 2400 & 193 & 32500 & 264.938 & 0.032 & 1320.41 & 52.82 \\
\hline
\end{tabular}

Sumber : Hasil Analisis

Pada tabel 4 dapat kita lihat bahwa secara perhitungan teori momen kapasitas terbesar ialah pelat beton bertulang dengan tulangan konvensional diameter $8 \mathrm{~mm}$ dengan nilai $\mathrm{Mn}=1320,41 \mathrm{Kg} . \mathrm{cm}$, namun pada saat pengujian laboratorium ternyata momen kapasitas terbesar terdapat pada pelat beton bertulangan wiremesh M8 dengan nilai Mmax $=57500 \mathrm{Kg} . \mathrm{cm}$.

Namun seperti yang terlihat pada tabel 4 hasil analisis bahwa momen kapasitas hasil pengujian laboratorium lebih besar disbanding momen kapasitas teori jadi bisa dikatakan bahwa keempat besi tulangan pelat beton diatas layak untuk digunakan.

\section{KESIMPULAN}

Berdasarkan hasil pengujian dan hitungan yang dilakukan dapat disimpulkan sebagai berikut:

- $\quad$ Nilai uji kuat tarik besi tulangan diameter $8 \mathrm{~mm}$ pada $\varnothing 8$ $=441.61 \mathrm{~N} / \mathrm{mm}^{2}$ dan $\mathrm{M} 8=382.48 \mathrm{~N} / \mathrm{mm}^{2}$ sedangkan nilai kuat tarik pada besi tulangan diameter $6 \mathrm{~mm}$ pada $\varnothing 6=406.94 \mathrm{~N} / \mathrm{mm}^{2}$ dimana besi- besi tersebut telah memenuhi standar sebab nilai kuat tariknya lebih dari yang direncanakan $(\mathrm{fy}=240 \mathrm{MPa})$.

- $\quad$ Nilai uji kuat lentur pelat beton bertulang diameter 8 dimana $\varnothing 8=32500 \mathrm{Kg} . \mathrm{cm}$ sedangkan M8 $=57500$ $\mathrm{Kg.cm}$ dan pada pelat beton bertulang diameter 6 nilai kuat lenturnya ialah $\varnothing 6=45000 \mathrm{Kg} . \mathrm{cm}$ sedangkan M6 = $42500 \mathrm{Kg} . \mathrm{cm}$

- Sesuai hasil pengamatan penelitian, pelat beton dengan tulangan wiremesh lebih menunjukan perilaku kemampuan menerima beban, serta momen kapasitas yang lebih baik dalam melentur dibanding dengan pelat konvensional.

\section{DAfTar Pustaka}

[1] ACI Committee 544. (1989) Measurement of Properties of Fiber Reinforced Concrete. Report: ACI 544,2R-89.

[2] ACI Committee 544. (1993) Guide for Specifying, Proportioning, Mixing, Placing and Finishing Steel Fiber Reinforced Concrete. Report: ACI 544,3R-93.

[3] Bayasi, M. Z. and Soroushian, P. (1992) Effect of Steel Fiber Reinforcement on Fresh Mix Properties in Concrete. ACI Material Journal, V. 89, No. 4, pp. 369-374.

[4] Departemen Pekerjaan Umum Badan Penelitian Dan Pengembangan P.U, Pusat Penelitian Dan Pengembangan Pemukiman, Bahan-bahan Bangunan Memakai Semen untuk Pemukiman (Cement Based Building Materials), Jakarta.

[5] Departemen Pekerjaan Umum.(1989), SK SNI M-14-1989-F. Metode Pengujian Kuat Tekan Beton. Yayasan LPMB, Jakarta.

[6] Dipohusodo, Istimawan. (1994), Struktur Beton Bertulang. Gramedia Pustaka Utama, Jakarta.

[7] Nawy, EG. (1998) Beton Bertulang Suatu Pendekatan Dasar, PT. Refika Aditama, Bandung.

[8] Park, R. and Paulay, T. (1975), Reinforced Concrete Structures. John Willey \& Sons. New York. 